\title{
Pemberdayaan Ibu PKK Sebagai Kader Pengelolaan Faktor Risiko Hipertensi
}

\author{
Sherly Usman', RR.Yuningtyaswari² \\ 1,2 Program Studi pendidikan Dokter, Fakultas Kedoteran dan ilmu Kesehatan, Universitas Muhammadiyah Yogyakarta \\ Email: sherlyusman@umy.ac.id \\ DOI: $10.18196 / p p m .34 .294$
}

\begin{abstract}
Abstrak
Hipertensi adalah penyakit tidak menular tertinggi di Sleman tahun 2017. Kebanyakan penderita hipertensi yang telah terdeteksi tidak menyadari kondisinya. Hipertensi dapat dicegah apabila faktor risiko dikelola dan dikendalikan. Dalam pandemi Covid-19, warga khawatir kontrol rutin kesehatannya ke layanan kesehatan. Hal ini berdampak pada peningkatan risiko dan komplikasi kasus hipertensi. Pelatihan dan pendampingan ibu-ibu PKK sebagai kader penting agar dapat membantu warga dusun ngemplak untuk memantau tekanan darah tanpa harus ke layanan kesehatan. Tujuan kegiatan ini menghasilkan kader dari ibu PKK yang memiliki pengetahuan lebih mengenai hipertensi. Metode: Kegiatan diawali mengukur pengetahuan mengenai hipertensi dan hiperurisemia calon kader dengan memberikan pretes. Setelah itu dilanjutkan memberikan pendampingan dan pelatihan kepada 10 peserta kader secara online dengan memberikan panduan modul pengetahuan dan pemeriksaan tekanan darah dan leaflet mengenai pengetahuan asam urat. Di akhir kegiatan, pemberian postes diberikan untuk menilai hasil pendampingan dan pelatihan para kader. Selanjutnya hibah alat kesehatan kepada kader untuk pemeriksaan kepada warga dusun ngemplak, Donoharjo, Sleman. Hasil kegiatan dan Implikasi: meningkatnya pengetahuan kader mengenai hipertensi dan hiperurisemia. Para kader dapat berpartisipasi dan membantu memeriksa tekanan darah warga ketika dilaksanakan agenda pemeriksaan kesehatan warga. Kesimpulan: peningkatan pengetahuan para kader dapat meningkatkan pengelolaan faktor risiko hipertensi.
\end{abstract}

Kata Kunci: Kader Ibu PKK, Hipertensi

\section{Pendahuluan}

Menurut data awal dari Sampel Registration Survey tahun 2014, hipertensi adalah penyebab kematian nomor lima tertinggi di Indonesia. Hipertensi atau tekanan darah tinggi disebut juga sebagai penyakit sillent killer, penyakit ini telah menyebabkan banyak kematian didunia, dan prevalensi penyakit ini diperkirakan akan terus meningkat hingga sekitar 29\% pada tahun 2025. Prevalensi kejadian hipertensi di daerah D.I Yogyakarta yaitu sebesar 26\% dan menempati peringkat nomor tiga penyakit hipertensi di Indonesia. Berdasarkan Surveilans Terpadu Penyakit Puskesmas pada tahun 2015 penyakit hipertensi menempati peringkat kedua dalam sepuluh besar penyakit yang sering muncul di D.I Yogyakarta. Kasus hipertensi menjadi kasus penyakit tidak menular tertinggi di Kabupaten Sleman pada tahun 2017 dengan prevalensi sebesar 12.204 per 100.000 penduduk.

Hipertensi meningkatkan risiko penyakit jantung dua kali dan meningkatkan risiko stroke delapan kali dibanding dengan orang yang tidak mengalami hipertensi. Selain itu hipertensi juga menyebabkan payah jantung, gangguan pada ginjal dan retinopati. Hal ini akan membahayakan jika tidak dikontrol dengan baik. Penderita hipertensi pada umumnya tidak menyadari keadaannya, sementara penderita hipertensi yang telah terdeteksi tidak menyadari kondisinya (Hasyim dkk., 2014). Padahal hipertensi merupakan penyebab utama penyakit jantung, otak, syaraf dan kerusakan hati dan ginjal sehingga membutuhkan biaya besar untuk menangani komplikasi yang ditimbulkan (Mustafiza, dkk., 2010). 
Hipertensi dapat dicegah apabila faktor risiko dapat dikelola dan dikendalikan. Faktor risiko hipertensi antara lain pola hidup seperti merokok, garam berlebih, obesitas, aktifitas fisik dan stress (Fadlilah, dkk, 2018). Pemantauan kadar tekanan darah dan asam urat secara berkala dapat mengendalikan angka kejadian hipertensi dan hiperurisemia. Tekanan darah sistolik yang terkontrol dapat menurunkan angka kematian akibat penyakit kardiovaskular, stroke, dan gagal jantung (Dipiro, dkk., 2011; Soenarta, dkk., 2015). Oleh sebab itu, pemeriksaan tekanan darah dan kadar asam urat penting dilakukan secara rutin dan terkontrol. Permasalahan lainnya yang timbul selama pandemi covid-19 ini yaitu turunnya layanan kesehatan di pelayanan kesehatan khusus penyakit noncommunicable diseases (NCDs). Hal ini terjadi karena meningkatnya kasus covid-19 sehingga layanan kesehatan terpusat pada layanan covid-19. Dari sumber BPJS kesehatan juga menyatakan bahwa kunjungan masyarakat ke rumah sakit menurun selama pandemi ini. Masyarakat merasa khawatir tertular covid-19 apabila datang memeriksakan kesehatannya ke rumah sakit.

Permasalahan mitra yang ditemui adalah menurunnya kualitas kesehatan warga dusun ngemplak selama masa pandemi covid-19 ini. Keadaan pandemic covid-19 mempengaruhi pola warga untuk rutin kontrol ke layanan kesehatan. Kesadaran warga untuk kontrol kesehatann menjadi menurun karena adanya rasa khawatir untuk memeriksakan kesehatan metabolik di layanan kesehatan. Dengan kegiatan pemberdayaan ibu-ibu PKK di dusun Ngemplak sebagai kader menjadi satu hal yang memiliki peran penting. Adanya kader dapat membantu warga untuk memeriksa, tanpa harus datang ke layanan kesehatan. Selain pandemi covid-19, hal lainnya yang menjadi permasalahan mitra adalah masih rendahnya sarana dan prasarana pemeriksaan umum di pos kesehatan dusun. Dengan hibah alat-alat pemeriksaan kesehatan umum dari kegiatan ini, dapat membantu meningkatkan sarana dan prasarana di pos kesehatan dusun.

Dengan demikian, kegiatan pembekalan dan pembinaan mengenai pengetahuan dan keterampilan screening hipertensi kepada kader serta hibah alat-alat kesehatan, dapat membantu para warga dusun ngemplak, donoharjo, sleman untuk memeriksakan tekanan darah dan asam urat tanpa harus ke layanan kesehatan. Selain itu dapat sekaligus meningkatkan sarana dan prasarana untuk pemeriksaan kesehatan warga dusun. Kegiatan pemeriksaan faktor risiko dan screening hipertensi dapat dilakukan melalui kegiatan berkala ibu-ibu PKK di dusun Ngemplak, Donoharjo, Sleman dengan alat-alat kesehatan yang lebih memadai.

\section{Metode Pelaksanaan}

Kegiatan ini dilakukan dengan beberapa tahapan, dimulai sejak proses administrasi perijinan kepada kepala dusun dan ketua PKK yaitu:

1. Penyampaian informasi dan sosialisasi kepada kepala Dusun Ngemplak, Donoharjo dan ketua PKK.

2. Permohonan data dan identitas peserta ibu-ibu PKK sebagai calon kader yang diberikan oleh ketua PKK berdasarkan kesediaan dari anggota ibu-ibu PKK. Proses pengambilan data dan identitas calon kader ini dilakukan secara online dengan mengisi form dengan link https://forms.gle/h1RiQYwWa5tkNREh8

3. Kegiatan screening awal tingkat pengetahuan peserta kader mengenai tekanan darah dan hipertensi. Kegiatan screening ini bertujuan ntuk mengetahui seberapa jauh tingkat pengetahuan peserta kader mengenai tekanan darah dan hipertensi. Kegiatan ini dilakukan dengan Pengisian pretes secara online melalui link yang diberikan kepada peserta yaitu https://forms.gle/J5kDcawbuJLi1nas5.

4. Proses pendampingan dan pembinaan kader dengan pemberian materi mengenai cara pemeriksaan tekanan darah dan hipertensi. Pemberian materi dilaksanakan secara online 
melalui sharing dan diskusi secara online melalui via wa grup. Materi berupa modul dan leaflet untuk para kader berisi materi terkait definisi, maksud dan tujuan pemeriksaan tekanan darah, definisi keadaan hipertensi, faktor risiko, dan pencegahan hipertensi.

5. Penilaian dan Evaluasi Pengetahuan peserta kader mengenai hipertensi untuk mengetahui tingkat serapan dan manfaat yang diperoleh kader dari kegiatan ini. Proses ini dilakukan secara online dengan mengisi postes dengan link yaitu https://forms.gle/ScriwcU7JfsYvdoM6.

6. Kegiatan pemeriksaan dan screening hipertensi kepada warga dusun ngemplak oleh pada kader sebagai bentuk implikasi dari kegiatan ini.

7. Penyerahan dan hibah alat-alat kesehatan kepada para kader ibu-ibu PKK.

\section{Hasil dan Pembahasan}

Kegiatan pemberdayaan ibu-ibu PKK sebagai kader yang terampil dalam pengelolaan hipertensi telah terlaksana. Kegiatan yang memerlukan tatap muka langsung atau offline telah dilaksanakan dengan prosedur pencegahan penularan covid. Dari Hasil kegiatan diperoleh hasil yaitu antara lain:

1. Data dan identitas peserta ibu-ibu PKK sebagai calon kader

Dari hasil tanggapan surat pemberitahuan resmi dan rekomendasi kegiatan, kepala dusun dan ketua PKK dusun ngemplak memberikan informasi calon peserta kader yang telah bersedia menjadi kader. Peserta yang berpartisipasi berjumlah 10 peserta. Semua peserta kader bertempat tinggal di dusun ngemplak, donoharjo, sleman dan merupakan anggota ibu-ibu PKK.

Tabel.4 Data identitas Peserta Kader Ibu-Ibu PKK dusun Ngemplak, Donoharjo,Sleman,DIY

\begin{tabular}{|c|c|c|c|c|}
\hline Nama & $\begin{array}{l}\text { Usia } \\
\text { (Tahun) }\end{array}$ & Alamat & Pekerjaan & $\begin{array}{l}\text { Riwayat } \\
\text { Pendidikan }\end{array}$ \\
\hline Suminarsih & 47 & Ngemplak Donoharjo ngaglik Sleman & $\begin{array}{l}\text { Ibu rumah } \\
\text { tangga }\end{array}$ & SLTA \\
\hline Sri Ida Yanis & 51 & Griya Ngemplak asri no 120 & $\begin{array}{l}\text { Ibu Rumah } \\
\text { Tangga }\end{array}$ & S1 \\
\hline $\begin{array}{l}\text { LINA } \\
\text { ANDRIANI }\end{array}$ & 35 & $\begin{array}{l}\text { NGEMPLAK DONOHARJO NGAGLIK } \\
\text { SLEMAN }\end{array}$ & Swasta & SLTA \\
\hline $\begin{array}{l}\text { Dini iwanina } \\
\text { syarafina }\end{array}$ & 22 & Ngemplak Donoharjo Ngaglik Sleman & $\begin{array}{l}\text { Ibu rumah } \\
\text { tangga }\end{array}$ & SMK \\
\hline Ivana handayani & 35 & Ngemplak Donoharjo Ngaglik Sleman & IRT & SLTP \\
\hline Andari triliana & 31 & Ngemplak,donoharjo,ngaglik & $\begin{array}{l}\text { Ibu rumah } \\
\text { tangga }\end{array}$ & SLTA \\
\hline Sumiyati & 44 & Ngemplak,Donoharjo ,Ngaglik ,sleman & $\begin{array}{l}\text { Ibu rumah } \\
\text { tangga }\end{array}$ & SLTA \\
\hline Supartinah & 50 & $\begin{array}{l}\text { Ngemplak,rt } 01 \text { rw } 31 \\
\text { donoharjo,ngaglik,sleman }\end{array}$ & $\begin{array}{l}\text { Ibu rumah } \\
\text { tangga }\end{array}$ & D3 \\
\hline Titi saraswati & 42 & $\begin{array}{l}\text { Ngemplak RT } 2 \text { RW } 31 \text { donoharjo } \\
\text { ngaglik sleman }\end{array}$ & Irt & D3 \\
\hline Purwaningsih & 48 & Ngemplak, Donoharjo, Ngaglik, Sleman & $\begin{array}{l}\text { Karyawan } \\
\text { Swasta }\end{array}$ & SLTA \\
\hline
\end{tabular}




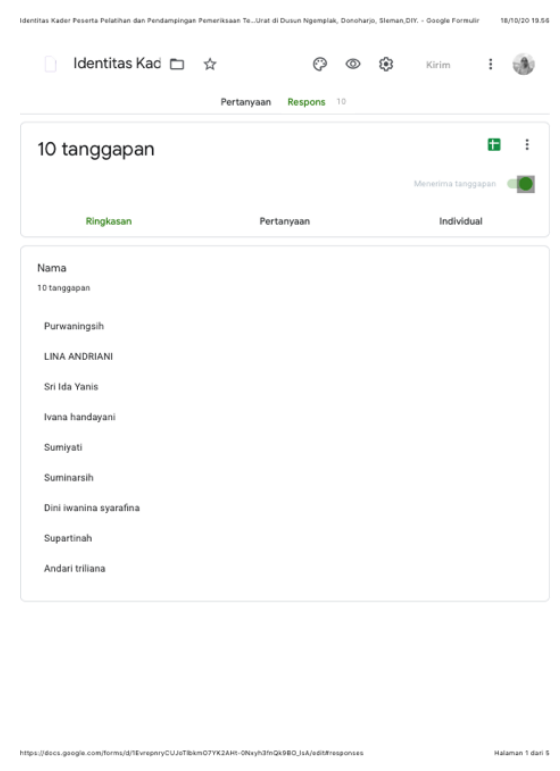

Gambar.1 tampilan awal rekap pengisian identitas peserta kader

2. Data screening awal tingkat pengetahuan peserta kader mengenai tekanan darah dan hipertensi. Kegiatan screening ini bertujuan ntuk mengetahui seberapa jauh tingkat pengetahuan peserta kader mengenai tekanan darah dan hipertensi.

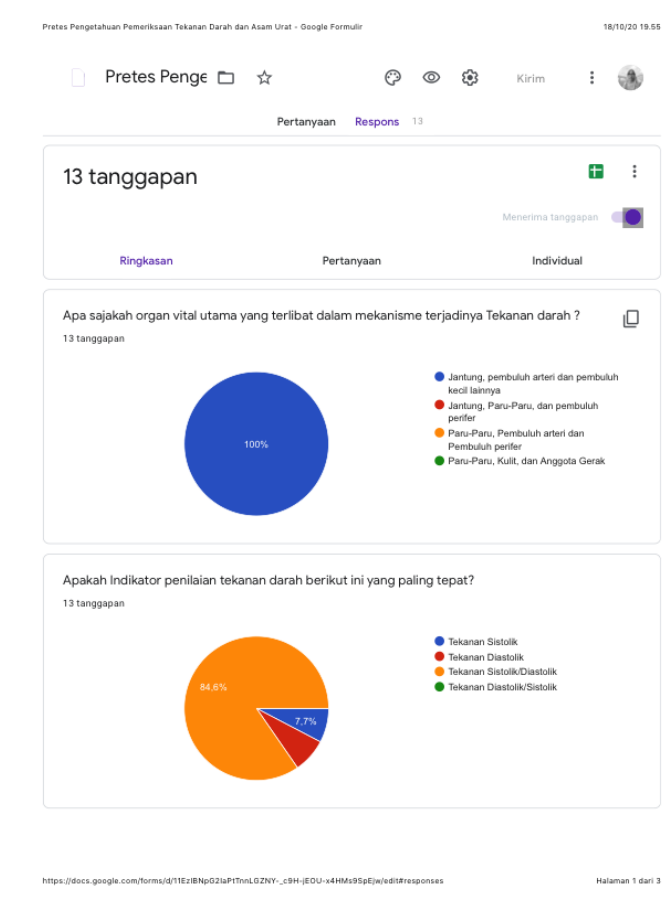

Gambar.2 Tampilan form rekap pengisian pretes secara online

3. Proses pendampingan dan pembinaan kader dengan pemberian materi mengenai hipertensi. Dari hasil pembelajaran modul dan leaflet ini kemudian peserta diberikan kesempatan untuk diskusi melalui online ataupun tatap muka secara langsung. Proses ini dilakukan selama 1 hingga 2 bulan. Selain itu juga dilakukan proses pelatihan dan 
pendampingan prosedur pemeriksaan tekanan darah yang baik dan benar. Proses diskusi dan konfirmasi mengenai modul yang telah dipelajari peserta juga dilakukan melalui wa grup atau tatap muka langsung. Proses pendampingan langsung dilakukan ketika para kader terlibat dalam kegiatan pemeriksaan kesehatan warga dusun ngemplak. Kegiatan ini secara langsung didampingi oleh dr. Sherly Usman.,M.Sc.
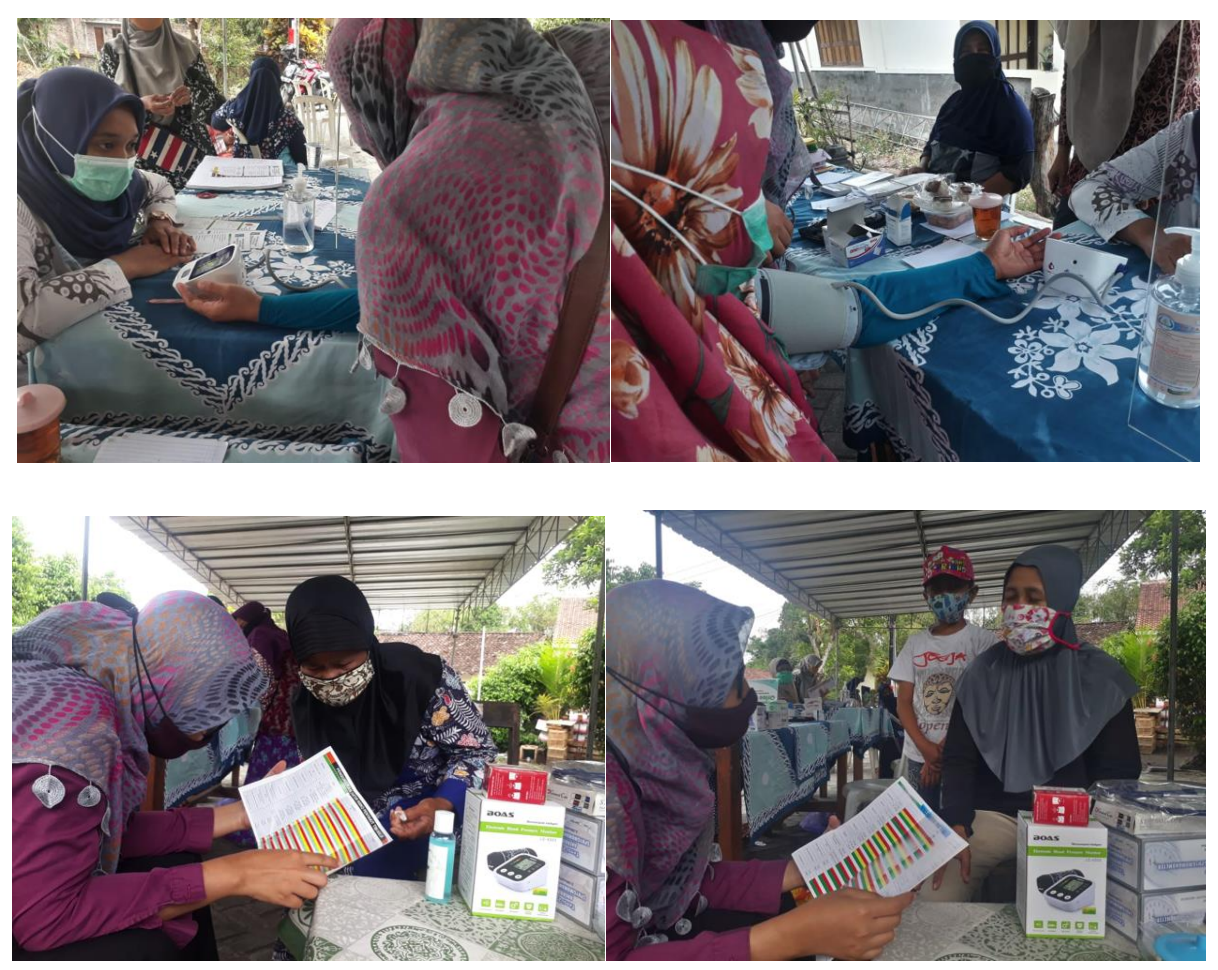

Gambar 5. Kegiatan pedampingan kader dalam pemeriksaan tekanan darah

4. Data Penilaian Evaluasi Pengetahuan peserta kader mengenai hipertensi setelah mengikuti kegiatan pelatihan dan pendampingan. Dari hasil evaluasi di dapatkan kenaikan ratarata nilai peserta kader. Dari hasil screening awal diketahui nilai rata-rata peserta yaitu 80 dan nilai hasil evaluasi setelah kegiatan pelatihan sebesar 90.

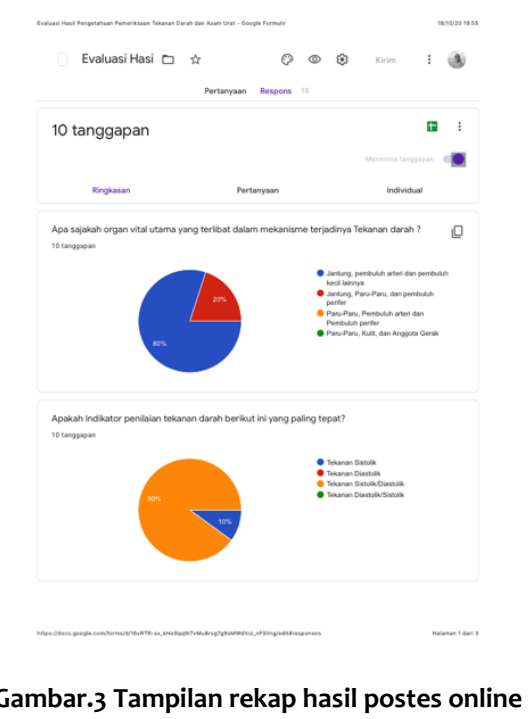




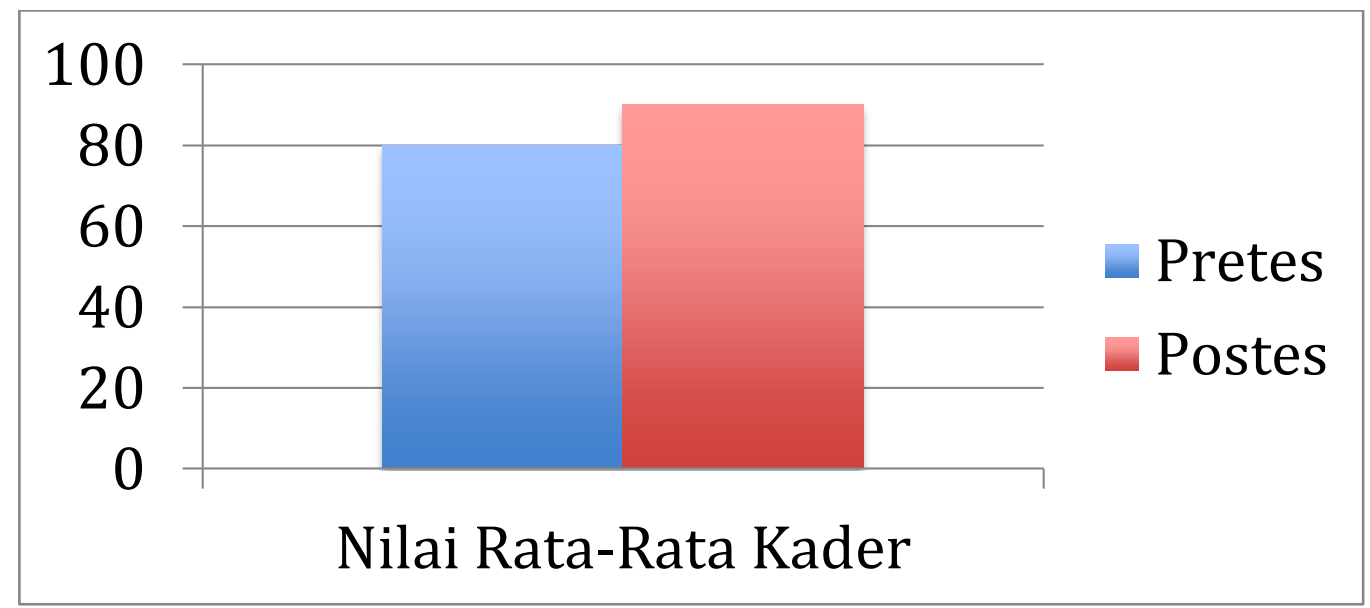

Gambar.4 Hasil nilai rata-rata pretes dan postes para kader

5. Kegiatan pemeriksaan dan screening hipertensi kepada warga dusun ngemplak oleh pada kader. Kegiatan ini diawali dengan sosialisasi pelaksanaan kegiatan oleh ketua PKK kepada warga untuk memeriksakan diri. Kegiatan ini dilaksanakan dengan menjalankan protokol pencegahan covid yaitu dengan pemeriksaan suhu, wajib memakai masker, mencuci tangan sebelum dan sesudah mengikuti pemeriksaan. Pada kegiatan ini, pos pemeriksaan tekanan darah dan asam urat dilakukan oleh kader langsung. Dari hasil kegiatan ini, didapatkan data hasil pemeriksaan tekanan darah dari warga yang datang untuk memeriksakan diri dan diketahui terdapat $35 \%$ warga yang memeriksakan diri menderita hipertensi.

6. Telah dilaksanakan hibah alat-alat kesehatan kepada para kader ibu-ibu PKK

Hibah alat-alat kesehatan diserahkan langsung oleh dr. Sherly Usman.,M.Sc sebagai ketua tim pengabdian, kepada yang mewakili para kader yaitu ketua PKK ibu Suminarsih. Alat-alat kesehatan ini akan digunakan dalam kegiatan pemeriksaan kesehatan para warga dusun ngemplak, donoharjo, sleman oleh para kader, sehingga secara tidak langsung dapat meningkatkan sarana dan prasarana pos kesehatan di dusun.

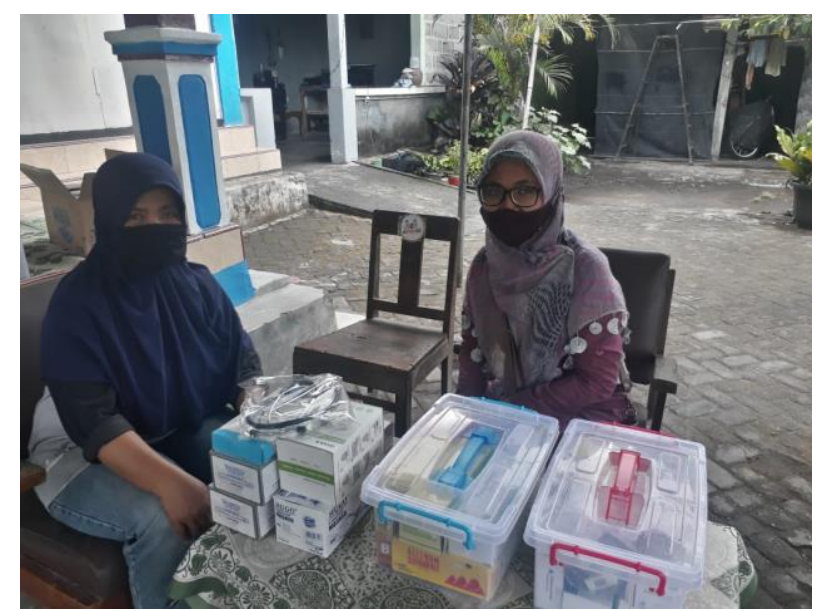

\section{Simpulan}

Dari hasil kegiatan pemberdayaan Ibu-Ibu PKK sebagai kader dalam pengelolaan faktor risiko hipertensi dapat meningkatkan pengetahuan dan keterampilan para kader sehingga dapat membantu melakukan screening hipertensi di dusun Ngemplak, Donoharjo,Sleman,DIY. Hibah alat-alat kesehatan dapat meningkatkan sarana dan prasarana kesehatan di pos kesehatan dusun.

\section{Ucapan Terima Kasih}


Ucapan terima kasih kepada lembaga penelitian, publikasi dan pengabdian masyarakat (LP3M) UMY atas dukungan materi dan pendanaan serta kepada pihak-pihak yang terlibat dan membantu dalam penyusunan data dan laporan.

\section{Daftar Pustaka}

Dinas Kesehatan. Profil Kesehatan Kabupaten/Kota se-DIY. Yogyakarta: Dinas Kesehatan D.I. Yogyakarta; 2015.

Dipiro, J., dkk. 2011. Pharmacotherapy: Pathophysiologic Approach.

Fadlilah, S., Sucipto, A., 2018. Analisis Faktor Yang Berhubungan dengan Kadar Asam Urat Pada Masyarakat Dusun Demangan, Wedomartani, Ngemplak, Sleman, Yogyakarta. Fakultas Ilmu Kesehatan, Universitas Respati Yogyakarta

Hasyim, M., Syahputra, B.,2014. Edukasi Penyakit Hipertensi, Asam Urat dan Diabetes Pada Warga Dusun Ngepuh Lor, Desa BanyuSidi, Pakis, Magelang, Jawa Tengah. Jurnal Inovasi dan Kewirausahaan. Volume 3 No. 3 Halaman 146-150

Mustafiza,P,V., 2010. hubungan antara hiperurisemia dengan Hipertensi, Fakultas Kedokteran Universitas Sebelas Maret Profil kesehatan kabupaten sleman 2018. https://dinkes.slemankab.go.id/wp-content/.../2018/.../PROFIL-KESEHATAN-2018-1

Soenarta, A.A., dkk. 2015. "Pedoman Tata Laksana Hipertensi pada Penyakit Kardiovaskular". Pedoman Tata Laksana Hipertensi pada Penyakit Kardiovaskuler, 1. Hlm. 1-2 